\title{
LIVING WITH MYSTERY: VIRTUE, TRUTH, AND PRACTICE
}

\author{
DAVID E. COOPER
}

Durham University

\begin{abstract}
This paper examines how a person's life may be shaped by living with a sense of the mystery of reality. What virtues, if any, are encouraged by such a sense? The first section rehearses a radical 'doctrine of mystery', according to which reality as it anyway is, independently of human perspectives, is ineffable. It is then argued that a sense of mystery may provide 'measure' for human lives. For it is possible for a life to be 'consonant' with this sense - through exercising humility, for example and even to emulate mystery. A further section corrects a misunderstanding about the connection between a sense of mystery and the virtues it invites, while a final section considers the relationship between living with mystery and religious faith.
\end{abstract}

The words 'living with mystery' may be heard in various ways. Maybe they suggest something like living with insomnia or some other unwelcome circumstance with which, nevertheless, a person defiantly copes. This, it seems, is how Albert Camus's Sisyphus lived with the 'absurd' situation of having to believe and act in a world that is unknowable, that keeps silent when questioned. ${ }^{1}$ Or perhaps a person lives with the mystery of things as do a couple of newly-weds who decide that, yes, they can live with the wallpaper in their new house. It's nothing to enthuse about, but it can be tolerated and with any luck ignored until something better can be afforded. To live with mystery in this sense is to put up with it, perhaps put it out of mind.

But when someone speaks of living with animals, say, or with music, the reference is probably to a life led in intimate association with them a life to a degree shaped and guided by a relationship to them. And this is sort of way I want the phrase 'living with mystery' to be heard. What

${ }^{1}$ Albert Camus, The Myth of Sisyphus, trans. J. O’Brien (London: Penguin, 1975), pp. $23 \mathrm{f}$. 
might it be for a life to be properly responsive to - shaped and guided by - a sense of mystery? How if at all might certain virtues - like humility take their place in such a life? And would it be a life with a character that invites the label 'religious'? These are the questions I ask in this paper.

\section{A DOCTRINE OF MYSTERY}

In order to provide these questions with a context, I need to explain what I have in mind by 'a sense of mystery', and what indeed the mystery is with which one is to live. So I'll briefly rehearse 'a doctrine of mystery' that I have defended in some detail in a number of earlier publications. ${ }^{2}$

The central claim of the doctrine is, quite simply, that reality as such - as it 'anyway' is, irrespective of human perspectives - is ineffable and mysterious. Here, 'mysterious' should be taken in a strong sense. The point is not that, due to our limited intelligence and resources, reality may for ever lie beyond our ken. It is, rather, that in principle no account of the world that we or other imaginable creatures might ever provide could count as a description of reality as such. Reality is not 'discursable', to speak with Kant: it is radically and inevitably ineffable.

This claim is entailed, in my view, by the rejection of two rival positions that, between them, exhaust the alternatives to a doctrine of mystery. First, there is the 'absolutist' view that there is indeed a way reality anyway is and that this is something which, in principle at least, can be articulated - by natural science perhaps, if not today's then an 'ideal' one of the future. Second, there is the 'humanist' view that while the world can indeed be described, this is only 'a human world' - one that, as Camus put it, is inevitably 'stamped' with a human 'seal'.

I've argued elsewhere that absolutism and humanism are each a combination of truth and error. The humanist is right to hold that description is necessarily of 'a human world', for any description cannot but reflect human interests, purposes and perspectives. 'You can't', as William James wrote, 'weed out the human contribution. ${ }^{3}$ Humanists err, however, in maintaining that the human world is all that there is. There is reality beyond the human. Absolutists are quite right, therefore, to recognize

${ }^{2}$ See David E. Cooper, The Measure of Things: Humanism, Humility and Mystery (Oxford: Clarendon Press, 2002); 'Life and Meaning', Ratio, 18 (2005), 125-37; and 'Mystery, World and Religion', in Philosophers and God: At the Frontiers of Faith and Reason, ed. John Cornwall and Michael McGhee (London: Continuum, 2009), pp. 51-62.

${ }^{3}$ William James, 'Pragmatism and Humanism', in The Writings of William James (Chicago: University of Chicago Press, 1977), pp. 449-60 (p. 455). 
this, but they err in supposing that this reality is discursable and effable. That it is ineffable is guaranteed by the humanist's correct insistence that nothing could be describable which purported to be entirely free from the human contribution, showing no sign of the human seal.

There is, if I'm right, just one way out of the impasse created once absolutism and humanism are both rejected. This is to embrace a doctrine of mystery - to hold that there is a reality beyond the human, but for that very reason a mysterious reality. Why maintain, however, that there is this mysterious reality? The answer, crudely, is that it is impossible to live or cope with the supposition that the human world is all that there is. To suppose this is to think that one's beliefs, commitments and purposes are subject, finally, to no measure beyond, in Sartre's words, 'principles man himself ordains. ${ }^{4}$ But this thought, I suggest, is a piece of hubristic posturing. Genuinely to be committed to beliefs and aims requires a sense that these are answerable to what is beyond the human. A belief or value which cheerfully acknowledges that it is simply the product of human ordinance or convention is bogus. And it is a type of arrogance to imagine that human beings possess the self-sufficiency to do without a sense of answerability to what is not of their own making.

This hubris of posture is matched by a different style of hubris on the part of absolutists. Theirs, quite simply, is the conceit of supposing that human beings possess the capacity to transcend their condition so as to attain an objective vision of reality free from the human contribution a capacity to soar above all purposes and perspectives.

A doctrine of mystery, by contrast, is doubly blessed with humility. For to assent to it is to abandon the two hubristic pretensions - first, to a capacity to know and describe reality as it anyway is, and second to an ability to live without a sense of answerability and measure. Humility and hubris, so understood, are something of terms of art. But there are good precedents for my use of them. Nietzsche, for example, decried the (absolutist's) 'arrogant pride' in supposing we possess an 'organ of truth' enabling knowledge of reality as such, while Thomas Nagel condemns the (humanist's) 'lack of humility' in supposing that the world is simply 'our world', the human world. ${ }^{5}$ As these and other precedents suggest, my

${ }^{4}$ Jean-Paul Sartre, Existentialism and Humanism, trans. P. Mairet (London: Methuen, 1966), pp. 55-6.

${ }^{5}$ Friedrich Nietzsche, Philosophy and Truth: Selections from Nietzsche's Notebooks of the Early 1870s, trans. D. Breazeale (Atlantic Highlands, NJ: Humanities, 1979), p. 80; Thomas Nagel, The View from Nowhere (New York: Oxford University Press, 1986), p. 109. 
use of 'humility' and related terms is, moreover, intelligibly connected to everyday uses. Indeed, it had better be - if a sense of mystery is able, as I claim it is, to give shape to a life in which virtues, like humility, have their place.

Someone will wonder, of course, how a sense of mystery in my strong sense of the term can guide or shape anything. If nothing can be said about the mystery which is beyond the human, how could appealing to it possibly yield any measure of human life? One would expect this scepticism from the scientific realists and humanists whom I have been criticizing - but doubts of a similar kind are also expressed, as we will now see, from quarters more hospitable to some aspects of my approach.

\section{THEISM AND MYSTERY}

In a number of recent books, John Cottingham has argued for a Christian, or at any rate theistic, conception of reality on grounds not dissimilar to those I have given for a doctrine of mystery. ${ }^{6}$ I have found it helpful to compare and contrast my position with his, and doing so certainly helps to prepare my case for the contribution that a sense of mystery may make to a good life.

Just as I argue for a reality that is beyond the human, so Cottingham urges the existence of a 'transcendent', indeed 'supernatural' reality that cannot be reduced to the world that is experienced through ordinary perception and explored by natural science (pp. 47, 78). And he does so on the basis of rejecting rival alternative conceptions that have easily discernible affinities to what I dubbed 'absolutism' and 'humanism'. Of particular interest is his rejection of 'secular naturalism' and an associated 'relativism' about value on the grounds that these are incapable of accommodating, or even making sense of, profound and abiding human aspirations. These are the 'basic human responses', 'deep yearnings', 'sensibilities and impulses' that inform and motivate our aesthetic, moral and spiritual lives (pp. 13, 15, 19). Naturalists and relativists, to be sure, pretend to be able to accommodate such responses - to make room, for instance, for humility, gratitude, love, wonder and beauty - as products of human commitments. But, precisely because they are no longer perceived as 'values we did not create' and as reflecting 'a perfection ...

\footnotetext{
${ }^{6}$ See, for example, John G. Cottingham, The Spiritual Dimension: Religion, Philosophy and Human Value (Cambridge: Cambridge University Press, 2005) and Why Believe? (London: Continuum, 2009). Pages references in the text are to this second work.
} 
not of our own making', these 'secular analogues' are 'inauthentic' and without a genuine 'power' to command allegiance (pp. 4, 15, 95). Like myself, Cottingham discerns in the pretence of naturalists and relativists a kind of hubris, an unrealistic and vainglorious 'dream of autonomy and self-sufficiency' (p. 3), for it is the pretence to live without a sense of humanity's subjection to objective measure.

This measure, for Cottingham, is provided by the God of Christian and perhaps other theistic creeds. 'For the theist ... God himself is in his essential nature merciful, compassionate' and possessed of other virtues, so that when we act virtuously 'we are drawn closer to God, the source of our being, and the source of all that is good' (p. 41). As this remark implies, the theist is able to know at least some aspects of God's 'essential nature'. His God is, in certain essentials, entirely effable. And Cottingham is explicit that the unknowable divine reality of mystics cannot provide the measure we are unable to do without. 'There has to be at least something that can be validly said of God', if He is to command devotion and to be recognized as the source of the good (p. 65).

So, despite the affinities between my position and John Cottingham's, there is this difference: he is a theist, I am not. I subscribe to a doctrine of mystery; he does not. My 'beyond the human' is insufficiently discursable to count as Cottingham's divine source of the good. His God, meanwhile, is too discursable to count, for me, as beyond 'the human world'.

But it is not the respective metaphysical merits, as it were, of the two positions that is my present concern. This, rather, is with whether Cottingham is right to deny that a doctrine of mystery can provide measure and guidance for our lives. Is he right to hold that only a theistic framework 'provides a secure home' for such attitudes as 'humility, hope, awe, and thankfulness' (p. 163)? Is he right to take me to task, albeit politely, for imagining that the ineffable 'impersonal flux' to which Buddhists refer might 'find a genuine place' for such attitudes (p. 170)? In the following sections, I hope to show he is not right.

\section{CONSONANCE AND EMULATION}

In this section, I propose that mystery may find a place for virtues such as humility and compassion in two ways. First, the exercise of these virtues is consonant with a life informed by a sense of mystery. Second, their exercise might intelligibly be held to emulate what is mysterious. In the following section, I protect these proposals by challenging a modern 
conception of moral philosophising different from an older one more congenial to proposals like mine.

I urged earlier that a sense of mystery is 'in the truth', for the absolutism and humanism to which a doctrine of mystery is the sole alternative are untenable accounts of reality. People should, I'm going to assume, try to live 'in the truth' - to lead lives that are consonant with what they take to be an authentic sense of how things are. Now it is obvious, I think, that various attitudes, ambitions and stances are not consonant with a sense of mystery. Instead, they are ones consonant with absolutist or humanist doctrines. They are not consonant with a sense of mystery since they occlude, or otherwise cause to atrophy, this sense.

These dissonant stances are ones that are marked by one or other form of the hubris referred to earlier. Consider, first, what might be dubbed the Promethean stance that is the natural associate of the robust humanism according to which human beings are answerable to nothing but their own schemes, commitments and the tables of values they themselves have constructed. The Promethean stance is one of admiration for the alleged virtues of strong commitment, self-sufficiency, creativity, autonomy, authenticity and individuality. It is these virtues, as the Promethean sees it, that properly chime with - are consonant with - the true relationship of human beings to their world. As the free producers of this world, and of the truths and values to be found there, human beings must admire above all else the virtues of creative production. It is no surprise, therefore, to find that it is in philosophical tendencies like existentialism or constructivism, with their insistence that a human world is all that there is, that these virtues are prominent.

Consider, next, the 'scientistic' stance which is the natural bedfellow of absolutism in its currently most fashionable form, that of scientific realism. The scientistic stance is one that privileges a natural scientific account of the world, thereby encouraging reductions of the world so as to fit this account - a reduction, for instance, of living beings to 'vehicles for genes'. It is a stance which promotes a host of evaluative attitudes impatience, for example, with scruples about the individuality of animals that might obstruct genetic engineering programmes of shunting genes around from one species to another. The scientistic hero is the detached, objective enquirer, entirely free of sentimentality - of, that is, feelings and responses which, while they may once have been of adaptive advantage, have no place in cool, rational examination of what people should do. For the scientistic mind, sentimentality and allied vices are vices precisely 
because of their dissonance with the natural scientific appreciation of how the world objectively and ultimately is.

And now consider, by contrast, a stance more consonant with a sense of mystery. Prominent in this stance is humility. For humility is the antidote to the hubris apparent in the Promethean and scientistic stances. The person who lives with a sense of mystery is free, for a start, from Promethean confidence in people's capacity to achieve autonomy and self-sufficiency and to live honestly and well through the pursuit of these. This is the dangerous pretence or posture that, as he recounts, the nature writer Richard Mabey came to reject. He describes how 'disorientating' he eventually found the pressure to exercise individuality, freedom and 'choice' that these alleged virtues exert. Indeed, it is 'a block to more spontaneous, organic changes'. More important than 'choice', he realized, was 'to find a way of "fitting" ... [of] going with the flow' of things. It was when he succeeded in re-engaging with the flow of the natural world - with, say, the rhythm of bird migrations - and in regaining a way of 'fitting' with it, that Mabey emerged from a severely depressed condition. ${ }^{\text {? }}$

If the humble person is liberated from Promethean pretensions, so he or she is from the arrogant scientistic elevation of a particular view of reality. For someone possessed of a sense of mystery, the natural sciences provide an important, yet parochial account of the world, with no greater title to objectivity than countless other possible accounts - accounts reflecting concerns and ambitions very different from those of the natural sciences. This person is thereby freed, as well, from a hubristic confidence in an allegedly unsentimental, forthrightly technological management of the world, and of the beings which belong in it, that the parochial account serves to motivate.

Liberation from Promethean and scientistic pretensions attests to an appreciation on the part of the humble person of a dependence on what is neither of human making nor within the compass of human knowledge and discourse. This is not the sense of dependence experienced by the theist - the Sufi adept, say, or a disciple of Kierkegaard - who regards himself as 'nothing' in comparison with his God. But it is an appreciation, nevertheless, of a radical dependence inspired by recognition of the relationship of human beings to reality.

Here, then, is how a virtue - humility - may be consonant with a sense of mystery and, in this respect, be found a place by a doctrine of mystery.

${ }^{7}$ Richard Mabey, Nature Cure (London: Chatto \& Windus, 2005), p. 74. 
Might living with mystery also find a place for this and other virtues through emulating the reality of which the mystic has a sense? A negative answer to this question, we saw, is given by theists, like Cottingham, for whom it is only a 'person-like' God that human beings can emulate or 'draw close' to, by manifesting, however imperfectly, the virtues which God pre-eminently possesses.

I don't have the space to make good the suggestion that there can also be emulation of what is mysterious and ineffably beyond the human. But there would, surely, be something itself smacking of hubris in dismissing an idea that has been central to several spiritual traditions. Neo-Platonists, for example, maintained that the ascetic, disciplined and intellectual life brought a person closer to the Good or the One - to the ineffable source of everything - than a sybaritic, lax and sensuous life. This is because the former life is freer from immersion in and subjection to matter. And while nothing positive can be asserted about the One, it is nevertheless legitimate to assert that it is nothing material.

Daoism, perhaps, provides the best example of a spiritual dispensation that calls for the good life, that of the sage, to emulate the impersonal, and ineffable, Way of reality. The 'constant' Way - dao - cannot, as the opening chapter of the Daodejing reminds its readers, be spoken of, but the authors of the text concede, indeed stress, that one may say what dao is not. As the wellspring of everything, it cannot be bound by anything outside itself and is therefore without any obstacles to overcome and devoid of partiality and aggressive purpose. Dao, therefore, invites figurative description as 'gentle', 'spontaneous', and 'non-contending'. And these are precisely the terms that name the Daoist virtues. The sage adopts the way of $w u$ wei, literally 'non-action', but in effect a spontaneous, responsive style of living that eschews the rules and goals that constrain most people's behaviour and encourage them to be aggressive and contentious. ${ }^{8}$

I find nothing absurd, nothing to dismiss out of hand, in the neoPlatonist's or the Daoist's sense that some lives are close to, indeed to a degree emulate, the way of reality - the way of the One, the way of the Way. A desire to draw close to one's God is not the only form in which people manifest a yearning to experience a unity with the reality that encompasses them. (One thinks of the contemporary rhetoric of

${ }^{8}$ On Daoist spontaneity and other virtues, see David E. Cooper, Convergence with Nature: A Daoist Perspective (Dartington: Green Books, 2011), which draws on A.C. Graham's Introduction to his Chuang Tzu: Inner Chapters (Indianapolis: Hackett, 2001). 
recapturing a lost 'oneness' with nature.) And if I'm right not to dismiss these and many other comparable views, then here is another potential strategy for finding a place for virtues within a doctrine of mystery.

\section{INFERENCE AND RESPONSE}

But here is a predictable challenge to my attempt to find a place for virtues within such a doctrine. Surely, someone will urge, it is perfectly possible to concede that there is mystery - and to reject the absolutist and humanist alternatives - but then sensibly to ask whether one's life should be humble, compassionate and so on. Equally, it is possible to sympathize with, say, Daoist metaphors of the Way, but to deny that any particular practices and attitudes are entailed by them.

This challenge reflects the characteristically modern conception of moral philosophy as a process of inference. The moral philosopher is someone who argues - who, having established or assumed certain truths, infers from these that such-and-such actions or attitudes are morally required. Since I have produced no sound argument to the effect that acceptance of certain virtues is entailed by a sense of mystery, I have therefore failed, according to the modern conception of moral philosophy, to find a place for these virtues.

This challenge, however, would leave unmoved the ancient philosophers of mystery who inspire my own approach. It is often remarked that, for the ancients, philosophy was primarily 'a way of life' or a spiritual dispensation, and what is intended here is that the decisive aim of philosophy is not the production of sound arguments or inferences, but the transformation of human practice and feeling. Hence the emphasis - puzzling to the modern philosophical mind - placed by many of these thinkers on 'spiritual exercises' and disciplines of the body as ingredients in the philosophical life.

The Daoist, Buddhist or Neo-Platonic thinker did not first provide an account of reality and then argue or demonstrate that a certain life is therefore mandatory. Instead, he provided a vision that, if properly absorbed - 'deeply cultivated', as Buddhists put it - would have, as a natural response to it, a certain attunement and comportment towards the world. Indeed, the failure of the appropriate response on somebody's part would be sufficient reason to suppose that he or she has not fully absorbed or internalized the vision of reality. For example, the Buddhist doctrine that, in reality, there is only 'not self' has not been deeply 
cultivated by someone who fails to exercise compassion, for its exercise belongs to the very understanding of the doctrine. Virtue and wisdom, in dispensations like Buddhism, are inseparable: the vicious prove their lack of wisdom, while the wise necessarily manifest the virtues.

A virtue, then, is consonant with a doctrine of mystery, not because it is entailed by it, but because it is naturally felt to chime with it - to be a natural response to it - by someone in whom this sense goes deep. It is reasonable to speak, here, of the response being natural for, according to the ancient dispensations, what drops away when a sense of mystery goes deep, are various artificial obstacles to the life of virtue. The arrogance and hardness that infect our treatment of human beings and other living beings are the products of societies in which a true vision of the way of things has been occluded - by febrile economic pursuits, for example, or the hegemony of the natural sciences in our educational systems. When this vision is retrieved, these obstacles to the life of virtue wither away. A sense of mystery, one might say, finds room for the virtues by making room for them - by clearing from the soul or mind of a person the clutter of prejudices, ambitions, and 'wrong views' that have been denying air and space to the virtues.

The sage in these ancient traditions is not an expert in ethical ratiocination or casuistry, not an axiological genius who deduces what to do from how things are. Rather, the sage is one in whom the truth of things has so deeply penetrated that, spontaneously and naturally, he or she lives a life of virtue consonant with this truth. The sage succeeds in making room for the virtues in a doctrine of mystery, not through constructing a sound argument, but through clearing a space in which people may appropriately respond to a sense of mystery and live in natural consonance with it.

\section{MYSTERY, RELIGION, FAITH}

In this final section, I ask whether to live with mystery is to live religiously. My aim in raising this question is not to get stuck into perennial disputes about the meaning of 'religious', but to provide a context for adding some further strokes to my sketch of what it is to live with mystery.

A person does not qualify as religious simply through assenting to a doctrine of mystery and endorsing the kind of argument for mystery that I rehearsed earlier. But, then, nor does someone qualify as religious simply through assenting to the proposition that God exists and 
endorsing the ontological or cosmological argument for His existence. I agree, once more, with John Cottingham when he writes that 'patterns of behaviour and affective response' are 'a more significant indicator of the difference between atheism and theism' than acceptance or rejection of 'abstract metaphysical claims' (p. 164). And, more generally, I would endorse Gordon Graham's judgement that 'religion is primarily a way of living life' and 'letting it be shaped' in certain ways. '

My question therefore becomes this: is there enough in a life informed by a sense of mystery - in its practices and attitudes, in its shape - for this life to count as a religious one? Clearly there are aspects of this life which incline one towards applying the label - the exercise of such virtues of humility and compassion, an acute sense of dependence on what is supernatural or beyond the human, and a yearning to emulate the Way that is the source of the world. But there is an ingredient so far missing - one that some people would argue is essential in a life that could legitimately be described as religious. This is faith.

These people would include Kierkegaard, who argued vigorously that purely natural, rational religion is not really religion at all - precisely because of its denial of a place for faith. It is faith, arguably, that constitutes the tie to something beyond oneself that is implicit in the very term 'religion'. It won't follow, though, that this faith has to be, as it was for Kierkegaard, unfounded belief in a personal God. Indeed, it won't follow that faith must take the form of belief at all - not at any rate if the belief in question is detachable from (or only contingently connected to) the patterns of behaviour and response, the way of living a life, in terms of which, we just saw, religion is primarily to be characterized.

To elucidate the notion of faith, it is more promising, perhaps, to turn from a vocabulary of belief to one of resolve and confidence - of resolute confidence, if you like. And I want to suggest that there are at least two (related) modes of faith, understood as resolute confidence, which are entirely consonant with - or even integral to - a sense of mystery. If that's so, then the requirement of faith does not exclude living with mystery from the domain of the religious.

The first mode is a resolute confidence that, with sufficient effort, engagement, openness and patience, a person may achieve an attunement to mystery sufficient for intimations of how one's life should go, of how

${ }^{9}$ Gordon Graham, 'Religion and Theology', in Philosophers and God: At the Frontiers of Faith and Reason, ed. John Cornwall and Michael McGhee (London: Continuum, 2009), pp. 217-30 (p. 229). 
to respond to a sense of mystery. The confidence is that whether through virtuous practice, mindful attention, experience of art, engagement with nature, spiritual exercises or meditation, one will not be left perfectly stumm - without an inkling or intimation of mystery beyond the bare (metaphysical) thought that there is mystery. ${ }^{10}$ Were a person left like that, mystery would, so to speak, have failed him so that, with some justification, he might join Camus's Sisyphus in shaking his fist at reality. It is the sage's resolve or calling to surrender or become permeable to intimations of mystery by being rid of the obstacles that occlude a lived appreciation of mystery. This is a resolve or calling that would have no sense in the absence of confidence, of faith.

The second mode of resolute confidence is a confidence or trust in certain people - those sages or heroes whose lives seem authentically to answer to, and be given shape by, their intimations of mystery. They are men and women whose lives strike one as models of attunement to, and consonance with, mystery. They may be big names - Gautama, Zhuangzi, Plotinus, Shankara, or whoever. But they need not be. The hero could be a personal friend, a teacher or someone working in your office. The hero need not even be a real person, for the life of a fictional character - from the pages of Dostoievsky, perhaps, or Hermann Hesse - might provide a model in which people feel drawn to invest confidence.

What makes reference to confidence, resolve and faith apposite in respect of these heroes is a person's willingness to go where they go even when he or she does not understand why the hero took this or that step. After all, if you could work out why the steps are taken - and what, exactly, the direction is - you would not require a hero to lead you. Faith in the hero is comparable to trust in the guide who takes you through unknown territory. So, for example, I may have no idea what to expect from some meditative practice, no grasp of how it might provide intimations of mystery. But I know it to be the practice of people I recognize as heroes - men and women whose demeanour, style, speech, expression, gestures, eyes, and comportment fill me with a confidence that their way goes somewhere, that it is a way worth following.

The two modes of resolute confidence are, as these last remarks suggest, related. It is partly because certain people are not, as far as I can discern, left stumm and empty-handed by a sense of mystery that I am

10 These remarks draw on Michael McGhee's discussion of Buddhist 'faith' in his Transformations of Mind: Philosophy as Spiritual Practice (Cambridge: Cambridge University Press, 2000). 
able to invest confidence in them as heroes or sages. Confidence in them is thereby confidence in receiving something in return for cultivating or surrendering to a sense of mystery.

A doctrine of mystery, then, can have room for kinds of faith. When set alongside the virtues consonant with a sense of mystery and dependence, and with a yearning to emulate the source of things, this faith renders living with mystery a form of religious life. 